\title{
Book review of behind the shock machine
}

Volume 4 Issue 3 - 2015

\section{Opinion}

Book Review of

Behind the Shock Machine: The Untold Story of the Notorious Milgrim Psychology Experiments by Gina Perry $(2012,2013)$ The New Press, pp. 339.

As a Stanley Milgrim fan for decades, I was shocked by this book. That Milgrim's studies proved the susceptibility of all humans to peer pressure and obedience to authorities did not surprise me. But what I pride-fully learned from him, or thought I learned, was that a "minority of one" could at times help people decide NOT to hurt another person - a finding in one of Milgrim's variations of his obedience vignettes. In fact, I became a grumpy criticizer of perceived wrongdoing by others because public protests as "a minority of one," ala' Milgrim, against evil-doing could help reduce the evil-doing itself. I elaborated on this in several of my booksHappy Ending and Everybody For Everybody... and Soul of the Earth.

However, I am guilty of not pursuing a more in-depth review of Milgrim's work. Behind the Shock Machine summarizes the impact Milgrim's studies had on his subjects, who were duped more often than not into, so they thought, hurting fellow human beings. That the hurting was sham did not undo the fact that Milgrim's subjects believed they were hurting another when they obeyed him. In the long run, this troubled them greatly having succumbed to what was later to be morbidly seen as "being a good Nazi following orders." Most suffered from his experiments in retrospect, especially when "obedience" was seen to be linked to Adolph Eichmann's convincing German citizens to hurt other people, especially Jews. One finds that Milgrim's so-called "subjects" were turned into "objects." Milgrim tricked people into thinking they were somehow doing good by following orders, even if hurting another (Sieg Heil!).

Milgrim and those in charge were able to rationalize all their acts even though, on Perry's analysis, they actually depersonalized and dehumanized the participants, some of whom suffered in varying degrees ever since. The basic human decency of trust and truth fundamental to salutary human relationships was done away with. Milgrim's (and Eichmann's) deceptions are basically lies convincing people of "wanting to help by hurting other people"-But, in the final analysis, the giving of such orders is the bigger crime than being fooled into following orders. As described, it is disappointing that people would succumb, but they did; and, likely with same slick suggestibility, most others would too, unless there was a "minority of one" protesting (and sometimes that would not work either). One of Milgrim's admiring, but troubled subjects (also a Yale professor) academically rationalized his participation, closing with "You do not have to be a psychopath to follow orders" (Pg. 69) -to which I add "But you do have to be a psychopath to give the orders."

Also psychopathic perhaps is that Milgrim wanted the results he proclaimed to obtain, and he presented them dramatically creating his welcomed "genius" label. But "In over half of all his variations, Milgrim found the opposite result - that more than $60 \%$ of people disobeyed the experimenter's orders" (Pg. 9). Exploiting his sensational "findings," Milgrim overstated them, about which Perry

\author{
Samuel A Nigro M.D \\ Retired,Assistant Clinical Professor Psychiatry, Case Western \\ Reserve University School of Medicine, USA
}

\begin{abstract}
Correspondence: Dr. Samuel A Nigro M.D., Retired,Assistant Clinical Professor Psychiatry, Case Western Reserve University School of Medicine, 2517 Guilford Road, Cleveland Heights, Ohio 441 18, USA, Tel 216 932-0575, Email sam@docnigro.com
\end{abstract}

Received: October 15, 20I5 | Published: November 24, 2015

writes: "Their power [of the alleged "findings"] comes from what they'reSAID [emphasis added] to reveal: that in the face of authority, the human conscience is frail and unsubstantial" (Pg. 11).

Perry details the reactions of many subjects. Their struggling and suffered resistance have been suppressed and censored until now. Some subjects objected strongly to Milgrim, to my astonishment and some relief. Yet Perry maintains there was criticism: "Some felt strongly that this form of social science dehumanized participants, subjecting them to embarrassing and traumatic experiences in the name of science" (Pg. 235-36). She is too gentle. Milgrim proved and acted out authoritarian suggestibility going back to original sin, the story of Adam and Eve, and the listening to serpents.

No doubt, human values are lost in the face of authority and to anyone who has the glib ability to promote sensational or rationalized evil ideas. But Milgrim and his co-workers enjoyed the show as they tricked innocent people into thinking they were doing good, and they suppressed contradictory events. Even though the "hurting of others" was a sham in that no one was really hurt, the subjects still knew painfully that they psychologically succumbed and did what would have hurt others as they lived it. And the many resisters appear to have been co-opted and censored. And for some, the shame has never left.

Pretending to seek a goal, basic principles and "rules of decency" can be denied so that one acts out intrinsic evil - by hurting others for spurious reasons; by an absolute denial of intent; and by schmoozing false concern. It strikes me that the teaching of evil goals is easily available to every teacher morally derelict enough to try to do so. Peer pressure begins with the teachers who allow it to go on and who actually lead in such. Anti-transcendental themes from teachers authoritatively and sanctimoniously can trick students into obedience. Indeed, this is the basis for successful "conmen" whose glib confident tricks falsify and sanctify a goal. And they are often called "geniuses" - a label which has been applied not only to Milgrim, but to many of our celebrities, politicians, educators, journalists and media producers. Perhaps anyone wearing the genius label should put on a Nazi armband, not to indict, but to warn us gullible subjects. 


\section{Perry quotes Milgrim:}

In a naïve moment, some time ago, I once wondered whether in all of the United States a vicious government could find enough moral imbeciles to meet the personnel requirements of a national system of death camps, of the sort that were maintained in Germany. I am now beginning to think that the full compliment could be recruited in New Haven. A substantial proportion of people do what they are told to do, irrespective of the content of the act, and without pangs of conscience, as long as they perceive that the command comes from a legitimate authority. (Pg. 210).

And that is when it hit me: The abortion movement in the United States proves Milgrim correct. People can be convinced to do evil calling it good, but the real Nazi psychopaths are the celebrities, politicians, educators, journalists, Hollywood directors and media authorities telling each other and everyone else to do the "good" evil. And, consistent with their psychopathy, these authorities are more Nazi than they ever can allow self to be recognized. The same may apply to euthanasia and the bureaucratic interference with the traditional doctor-patient relationship. And to teachers of our children. And the punitive style of American law is now "KGB capitalism" as judges, prosecutors and investigators own investment stock in the prison industry.

The clinical aspects of Stanley Milgrim as described made me think of bipolar components. One of his students writes:

At times he could be playful, witty, and endearing. One day he replaced his speech with song, serenading instead of speaking, and refusing to respond to anyone who wouldn't sing back. He could also be warm and gracious. "I asked him if he would be my mentor, for example, and he acted like he had been just waiting for me to ask." At other times he was harsh and critical...He could be St. Nick one minute, Ivan the Terrible the next... Milgrim's mood swings between dictatorial and democratic, between charming and scathing - could have been fueled by his use of amphetamines, cocaine, and marijuana, a practice that began in his student years at Harvard (Pg. 242-243).

\section{And there you have it: Hero no more. Ditto for "genius."}

Over all, readers will get clear understanding of abuse of research subjects, arrogant self promotion, and the imposition of one's views as science. New to most of us commoners, Perry describes negative reviews which have had little impact on the sale of Milgrim's book Obedience to Authority, still in print today, or in diminishing Milgrim's universal referencing in psychological texts and writings. That the press and media ignore all this would fit their own purposes not to be seen as the imitators of Milgrim (or Eichmann for that matter). Consistent with that, are Perry's comment that "Milgrim's experiment can be viewed as a form of performance art" (Pg. 296) and "The obedience experiments might not be good science, but they are a powerful metaphor and artistic if not scientific triumph" (Pg. 301). Perhaps this is an accurate defining of the universal Authority Principle of "What Can I Get Away With?" and its universal answer of "Just about anything with today's anti-transcendent ('look at me' startle needing) press and media."

My conclusion is that this deplorable disregard of truth, oneness, good and beauty by anti-transcendental authority everywhere, with abuse of power, pseudo-science, press and media conspiracy and suggestibility, and absolute relativity, make one realize that everyone needs, more than ever, to know and live the genuine basic First Principles, the virtues and the ancient rules of civilization. Perhaps promoting "a minority of one" speaking up against evil is a beginning, and, if so, we can thank Milgrim for that reminder in spite of the rest of his work.

Finally, promoted should be the universal response to evil promoting authority: "You do it—not me!" Consistent with that, I offer another "minority of one": Two touted simple and safely effective procedures, easily done by anyone who knows how to have sex, should all be done, and only done, at Justice Centers or courthouses; and the procedures should only be done (conscience objections respected) by judges, prosecutors, attorneys, editors, journalists, and Hollywood directors taking obligatory turns performing any requested abortions and death with dignity needs of the citizenry. They want it done. They do it. Otherwise, we too are obedient dupes of Milgrim and Eichmann giving orders to do evil masquerading as good.

\section{Acknowledgments}

None.

\section{Conflicts of interest}

None.

\section{Funding}

None. 